\title{
Awareness and Importance of the Role of the Office of the Ombudsman in Selected Institutions in Zambia
}

\author{
Ramap David Binven Bedding*, Tawonga David Bedding \\ A Disertation Submitted to Zambia Open University for the Degree of Master in Criminal Justice System 2004 \\ *Corresponding Author: Ramap David Binven Bedding, A Disertation Submitted to Zambia Open \\ University for the Degree of Master in Criminal Justice System 2004
}

\begin{abstract}
The purpose of this study was to investigate levels of awareness regarding the functions of the Ombudsman Office Commission for Investigations office in the public service of the Republic of Zambia. It was assumed that the importance of this office are not well known by many Zambians. It was intended that the information will help to put a check on government activities in the interest of the citizens and thus the problem of human rights abuse, lack of accountability and abuse of governance will be somewhat curtailed The research design was a case study. The target populations for the study were Ministries, Parastatal, and Private Organization. Purposive sample was used. In order for the researcher to collect data questionnaires were used.

The finding showed that many people do not know the functions and importance of the operations of the Commission for Investigations of Zambia and many Zambians in the rural areas such as Districts have no ideas about the Commission for Investigations of Zambia \{Ombudsman of Zambia\}. There is a need to strengthen the operations of Commission for Investigations by acting promptly on the recommendations make. It is therefore felt that there should be a deliberate effort to treat the recommendations with the urgency they deserve.
\end{abstract}

\section{INTRODUCTION}

A continental rising or increasing of interest has taken grip on the need to establish the office of the Ombudsman as an instrument of Public Defender that would prevent unethical practices in Africa's public services. The office of the Ombudsman it is hoped would help the African public service to enthrone or place on a throne a self-check that would enforce accountability, prevent corruption and guide against maladministration. ${ }^{1}$ The Ombudsman office has been recognized as an office which in most Jurisdictions is provided for by the Constitution or by Act of Parliament and is headed by an Independent high level official called the Ombudsman. In Zambia the official is designated as the Investigator General. ${ }^{2}$

Apart from history of individual case studies of countries on their own, instituting the portfolio of the Ombudsman into their public sector practice in Africa, a wholesome approach to building an alternative mechanism for protecting the ordinary citizens against powerful state bureaucracy do not become popular. It is also worth mentioning that the International Ombudsman Institution (IOI), created in the $1970 s^{3}$ has promoted the spread of the International Ombudsman Institution. (IOI) operates as an international network with continental and sub-networks and its primary objective is to promote collaboration among member countries and experts. Currently, the Institute has over onehundred (100) member countries. ${ }^{4}$

\footnotetext{
${ }^{1}$ South Africa, Constitution of the Republic of South Africa Act 108 of $\{1996\}$, Pretoria: Government Printer.

2 Zambia's Ombudsman \{Commission for Investigation\} Guide: \{2012\}, Lusaka Zambia: Associate Printers.

3 Africa Ombudsman and Mediators Association, and African Ombudsman Research Center $\{2011\}$, South Africa Pretoria, Hillcrest Office Park, 175 Lunnon Street Lynnwood.

${ }^{4}$ A damolekun, Ladipo \{2000\}: Public Administration in Africa. Ibadan, Spectrum Books Limited.
} 
It has produced a "Handbook" for the training of newly appointed Ombudsmen worldwide. Countries are the African Ombudsman Association (AOA) $2003^{5}$ and the Association of Francophone Ombudsmen and Mediators (AOMF) established in 2001. The third annual conference of the latter was held in Tunisia in 2003, attended by 63 Ombudsmen and Mediators. Dr. Mukoro Akpomuvire $\{2006\}^{6}$

\subsection{Statement of the Problem}

Zambia has enjoyed a stable political and liberal democratic system of government since the country gained independence from British colonial rule in 1964. Zambia was one of the first countries in Africa and in Southern Africa to establish the office of Ombudsman \{Commission for Investigations $\}.{ }^{7}$ The country has had many of free and fair elections since 1964 which characterized by peaceful electoral process, and fair management. Election results are generally acceptable and accepted by all and electoral disputes are satisfactory handled by the Courts of the land.

The \{1990's and 2010's $\}$ witnessed the growth of populations from 9, million in the 80's $\{1980\}$ to 13.7 million in year $\{2010$.$\} National statistic report \{2010\}^{8}$ this growth in population also affects the growth in public service and other public institutions that engaged in employing the public Services as a whole.

The Zambian civil service has a problem coordinating its functions, resulting in failure to work effectively and leading to frustration and grievances among members of the public. This growth in both population and public service has resulted in corrupt practices, maladministration creeping into public administration system, ${ }^{9}$

The civil service has changed and expanded with the growth of the economic problems, the public service is no longer effective and efficient as it was, however, against giving the offices too much power, the Ombudsman's responsibilities are over looked by the corrupt officers, ${ }^{\mathbf{1 0}}$ and the power should be set out clearly to protect public from maladministration.

Social justice requires both that the rules be fair, and also that people play by the rules, hence a society's rules of 'fair play'. People deserve to be rewarded for their effort and productivity, punished for their transgressions, Dr. Raphael Arinaitwe \{May 10-12, 2010 ${ }^{11}$ treated as equal person's, and have their basic needs met. However, because these principles may come into conflict, it is often difficult to achieve all of these goals simultaneously. In addition, there are errors that lead to administrative deficiencies and thus the need of Ombudsman to mediate.

\subsection{Purpose of the Study}

The study was intended to promote the importance of awareness regarding the role of Ombudsman Institutions in Zambia, looking at the legal framework that is governing the structures of Ombudsman system in Zambia and its limitations and jurisdiction, and understanding the role of ombudsman and appreciating its existence in Zambia.

\subsection{Research Question}

\footnotetext{
${ }^{5}$ Africa Ombudsman Association Research Center $\{2011\}$

${ }^{6}$ MukoroAkpomuvire, $\{\mathrm{PhD}\}$ [Male] the Ombudsman Phenomenon in Africa States Public Service: \{2007\} Department of Local Government Studies, ObafemiAwolowo University, IIfe-Ife, Osun State, Nigeria.

${ }^{7}$ The African Ombudsman and Mediators Association \{AOMA\}; the African Ombudsman Research Centre \{AORC\}: \{2011\}, Hillcrest Office Park, 175 Lunnon Street Lynwood, Pretoria-South Africa.

${ }^{8}$ Ombudsman Institutions \& Minority Issues, Study by European Center for Minority $\{2010\}, \&$ Zambia Commission for Investigation Annual Report for the years \{1996, 1997 \& 1998\}.

${ }^{9}$ The Zambia Commission for Investigation 'Ombudsman Office' Annual Report for the years, $\{1996$

, 1997 \& 1998\}: \& an abstract of Anti-Corruption of Zambia Annual Report.

${ }^{10}$ Buleti G. Nsemukila PhD; $\{2000-2003\}$ : Joint Evaluation of Support to Anti-Corruption Efforts, Zambia Country Reports.

${ }^{11}$ RaphelArinaitwe PhDs ; $\{2010\}$ : A paper presented at Seminar in Morocco on Ombudsman Functions in African State.
} 
- Do many Zambians know the importance and function of the commissioner for investigation?

\section{LITERATURE REVIEW}

The Conception Definition of Commission for Investigations \{Zambia Ombudsman Ombudsman is an official, usually \{but not always appointed by the government or by parliament, who is charged with the responsibility of representing the interests of the public by investigating and addressing complaints reported by individual citizens \{Wikipedia: 2007\}. ${ }^{12}$ The office of the ombudsman serves as an appropriate institution for dealing with complaints from the citizens. It has the mandate to conduct inquiries concerning instances of maladministration in the activities of government. Hill $\{2000\}$ argued that the major work of the ombudsman is to serve as an agent for redress against arbitrary governments or administrative actions.

The duties of the Ombudsman in Zambia fall under the jurisdiction of the Commission for Investigations. \{Zambia Ombudsman\}. The Commission came into existence in $1973^{13}$ and commenced operation in $1974 .{ }^{14}$ The Commission for Investigation Act Chapter $39^{15}$ of the laws of Zambia established it. The Commission for Investigations redresses problems from members of the public and employers of public servants alike which takes place as a result of maladministration or abuse of office or authority by public institutions and officers. It offers a confidential, free and effective service due to the mandate granted it under the Commission for Investigation Act, and the Constitution of the Republic of Zambia.

The mandate of the ombudsman empowers him to investigate all public offices and officials up to the Vice President. In the main, the commission offers complainants many advantages in that the entire process of redressing dispute is at no cost to the complainant.

This encourages them to come forward to lodge their complaints. The commission is very independent because it is outside the control of any ministry or government officials, including the national legislature.

The Ombudsman of Zambia which is also called \{Commission for Investigations carry out their duties in two ways: first, they investigate complaints from members of the public; secondly they keep a brief watch on the agencies and institutions under their supervision \{ such as government offices, prisons, and courts \}, and instigate investigations of their own. At the end of the investigation the Ombudsman's powers are limited in making recommendations, but these are normally implemented.

However, administrative entities, like all other bodies which are creations of human beings and which are run by humans, are not infallible or wrong in matters of decision making or indeed in their actions. The Judicial System and the Parliamentary Committee Systems, while intended to provide checks and balances on the operation of Government, are not usually accessible to satisfy the day to day needs of ordinary people in Zambia. When people meet with difficulties in accessing basic services, back-up mechanism or system required to check the administrative actions of government institutions. When the review framework which provides a more accessible and user friendly service to the people or the public at large, and which compliments that of the Judiciary and Parliament, has been identified worldwide is the office of the Ombudsman.

The Commission is by law or statute is mandated to receive and investigate complaints from the public against acts of maladministration perpetrated by public service institutions as earlier mentioned in Chapter one of this paper. It is an independent organ or body of the state. It is empowered to obtain all the necessary information to facilitate investigations, and thereafter recommend corrective action, so as to obtain redress for deserving complaints. ${ }^{16}$

The Commission for Investigation $\{\mathrm{CFI}\}$ is charged with the responsibility of accepting and investigating complaints made by the public regarding the following:

\footnotetext{
${ }^{12}$ Ibid

${ }^{13}$ The Constitution of Zambia \{Constitution of UNIP\}\{1973\} Chapter 1 Part IX, Section 117.1 of the Laws of Zambia. Pp: 75.

${ }^{14}$ Commission For Investigations of the Republic of Zambia \{Ombudsman\} Annual Report for the year \{2002\}:

${ }^{15}$ The 1973 Constitution of the Republic of Zambia Chapter.1;Part IX ,Section 117.1 of the Laws of Zambia.

${ }^{16}$ Commission for Investigation \{Ombudsman\} Act of $\{1991\}$ : $\{$ Cap 39\} of the Laws of Zambia.
} 
A] any person in the service of the republic of Zambia; ${ }^{17}$

B] any member of a local authority; ${ }^{18}$

C] any person in the service of any institution or organization whether established by or under an Act of Parliament or otherwise, in which the Government holds a majority of shares or exercises financial or administrative control, for example, National Housing Authority, Zambia National Electricity Cooperation $\{$ ZESCO $\}$, Zambia Telephone Co-operation $\left\{\right.$ ZAMTEL\}, and many others ${ }^{19}$

D] any members and persons in the service of any Commission established by or under the Constitution or any Act of Parliament. ${ }^{20}$

The Commission has no power whatsoever to question any decision of the Court or of any Judicial Officer in the exercise of his judicial functions, or any matter relating to the exercise of the prerogative of mercy. Subsequently to that, all complaints as frivolous, vexatious, and those that are not made in good faith are rejected. ${ }^{21}$

\section{Methodology}

This chapter discusses the composition of the sample, data collection techniques, data collection procedures, and data analysis. It explains how the research was conducted; it also offers justifications for the methods used. The chapter also explains how the data were collected and processed.

\subsection{Research Design}

The research design used in this study was a case study and quantitative were used to collect data. Quantitative empirical method helped the researcher to contrast between the Ombudsman office and the public with questionnaires in which the respondents have to choose from various options from the questions. Qualitative helped the researcher with the understanding of Ombudsman rather than explanation; naturalistic observation rather than controlled measurement and subjective exploration of reality from the perspective of an insider as opposed to the outsider perspective that is predominant in the quantitative paradigm.

\subsection{Target Population}

The target population was made up of all classes of people from eight $\{8\}$ Ministries within Lusaka province; one parastatal; National Pension Scheme Authority \{NAPSA\}, the office of the Ombudsman general and Kabulonga Boys and Girls Lusaka district, United Nations Educational, Scientific, and Cultural Organization \{UNESCO\}. The members of staff for each ministry were given questionnaires. Both the schools; the parastatal and Ombudsman \{Investigator General Office\} were given questionnaires? The institutions mentioned above were given ten $\{10]$ questionnaires forms to answer or fill in.

\subsection{Study Sample and Sampling Techniques}

The sample comprised of two schools kabulonga boys and girls five $\{5\}$ member of staff each and five female and five male each, totaled ten $\{10\}$ questionnaires to each school, and all the institutions mentioned in target population above. The study employed a probability procedure using a stratified random sampling technique in order to obtain a representative sample in terms of proportions of the various group of member of staff in those ministries and institutions. According to Bless, and Achola $\{1988\}$, the stratified random sampling technique was only ideal for a study with a small sample size. When one has taken random sample, the findings can be generalized to the universal from which the sampling was taken. According to \{Pienaar 1980:359\} that random sampling ensures that any

\footnotetext{
${ }^{17}$ Ibid as above.

${ }^{18}$ Ibid as above.

${ }^{19}$ Commission for Investigations \{Zambia's Ombudsman\}: Bookplate $\{2013\}$ in title: If you have been unfairly treated by the Government Administration or experienced any maladministration in any organ of the Government, you may contact:

${ }^{20}$ Ibid

${ }^{21}$ Ibid
} 
artificial or false effects will be distributed evenly across all cases and that such false effect will be neutralized. It was further reported by Achola and Bless that the method was rarely used in social sciences research, but due to the small size of this study sample, the researcher felt that it was appropriate to use this method.

\subsection{Data Collection Instruments}

The member of staff, in the Ministries and the Parastatal, which random sampling were picked by virtue of them being member of staff in the sample. The researcher collected the data from all people or groups in the Ministries mentioned in this study, for the sake of comparison, and the questionnaires answered questions such as: are all member of the public knows the functions of Ombudsman in Zambia, do member of the public have access to office of Ombudsman in Zambia, do Zambians knows what is an Ombudsman means. The aspect of comparison was very necessary or not to be ignored. More than one strategy/source was used in collecting data.

Assist in providing the necessary checks and balance in the research. The following method was employed to collect data:

1. The researcher administered questionnaires, to member of staff for all the eight $\{8\}$ Ministries, two high school, two parastatal National Pension Scheme Authority \{NAPSA\} and Zambia's Ombudsman Office.

\subsection{Data Analysis}

The data was collected processed and analyzed using SPSS through quantitatively methods.

The analysis was recorded and arranged with Pie charts and Frequency or tables were also used.

\section{Presentation of Results}

This chapter contains the information collected through questionnaires.

\begin{tabular}{|c|c|c|c|c|c|c|}
\hline & Statements & Strongly Agree & Agree & Uncertain & Disagree & $\begin{array}{l}\text { Strongly } \\
\text { Disagree }\end{array}$ \\
\hline Q1 & $\begin{array}{l}\text { All members of the public } \\
\text { know the function of } \\
\text { Commission } \\
\text { Investigations }\end{array}$ & & & & & \\
\hline Q2 & $\begin{array}{l}\text { All members of the public } \\
\text { have access to the } \\
\text { Commission } \\
\text { Investigations }\end{array}$ & & & & & \\
\hline Q3 & $\begin{array}{l}\text { All members of the public } \\
\text { know what } \\
\text { Commission the } \\
\text { Investigations is } \\
\end{array}$ & & & & & \\
\hline Q4 & $\begin{array}{l}\text { Many Zambians know the } \\
\text { importance of the Zambia } \\
\text { Ombudsman }\end{array}$ & & & & & \\
\hline Q5 & $\begin{array}{l}\text { Have you ever heard of the } \\
\text { Ombudsman in Zambia }\end{array}$ & & & & & \\
\hline Q6 & $\begin{array}{l}\text { Are you interested } \\
\text { having access to } \\
\text { Ombudsman office of } \\
\text { Zambia }\end{array}$ & & & & & \\
\hline Q7 & $\begin{array}{l}\begin{array}{l}\text { Would you like to tell } \\
\text { others about } \\
\text { Ombudsman }\end{array} \\
\text { Zambia } \\
\end{array}$ & & & & & \\
\hline Q8 & $\begin{array}{l}\text { Do you think Zambia has } \\
\text { Ombudsman offices }\end{array}$ & & & & & \\
\hline
\end{tabular}

The table above shows the modified checklist used to collect information from the selected population. 
Awareness and Importance of the Role of the Office of the Ombudusman in Selected Institutions in Zambia

\begin{tabular}{|l|l|l|l|l|l|}
\hline TABLE AND CHART. 2. & Strongly Agree & Agree & Uncertain & Disagree & Strongly Disagree \\
\hline $\begin{array}{l}\text { All members of the public } \\
\text { knows the function of } \\
\text { Commission for } \\
\text { Investigations }\end{array}$ & 1 & 1 & 9 & 38 & 23 \\
\hline
\end{tabular}

\section{QUESTION THREE (3)}

All members of the public knows what the commission for investigation (Ombudsman-Zambia office) $30 \%$ disagree and 25\% strongly disagree with the above statement. $30 \%+25 \%=55 \%$ who are not in agreement of the statement $14 \%$ uncertain, $5 \%$ agree and $2 \%$ strongly agree adding up to $21 \%$

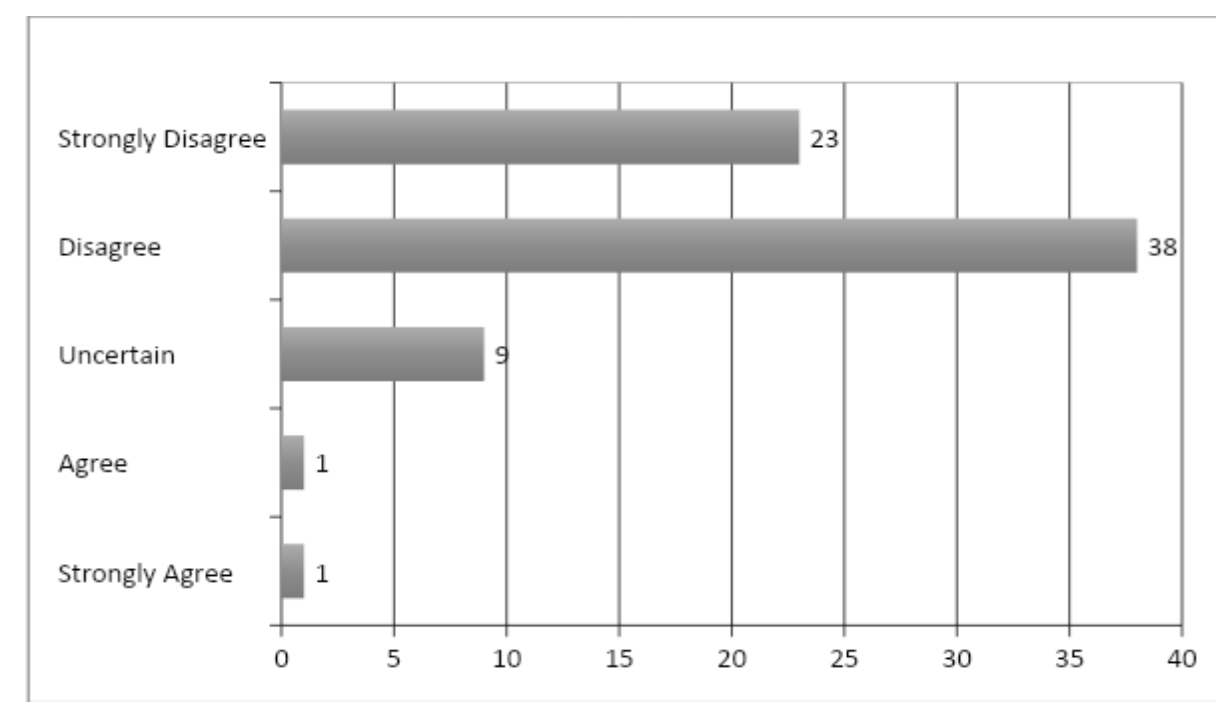

This cart shows that the number of people that disagree is $38 \%$ with the question that [All member of the Public knows the function of commission for investigations], while $23 \%$ strongly disagree, and $9 \%$ uncertain, but strongly-agree and agree have $1 \%$ each.

\begin{tabular}{|l|c|c|c|c|c|}
\hline TABLE AND CHART.5. & Strongly Agree & Agree & Uncertain & Disagree & Strongly Disagree \\
\hline $\begin{array}{l}\text { Many Zambians know the } \\
\text { importance of the Zambia } \\
\text { Ombudsman }\end{array}$ & 2 & 7 & 18 & 39 & 9 \\
\hline
\end{tabular}

\section{QUESTION FOUR (4)}

Many Zambians knows the importance of Ombudsman office of Zambia (Commission for investigation office) $39 \%$ Disagree and 9\% strongly disagree which adds up to $48 \%$. $18 \%$ are uncertain and $7 \%$ agree while $2 \%$ strongly agree with the statements giving a total of $27 \%$

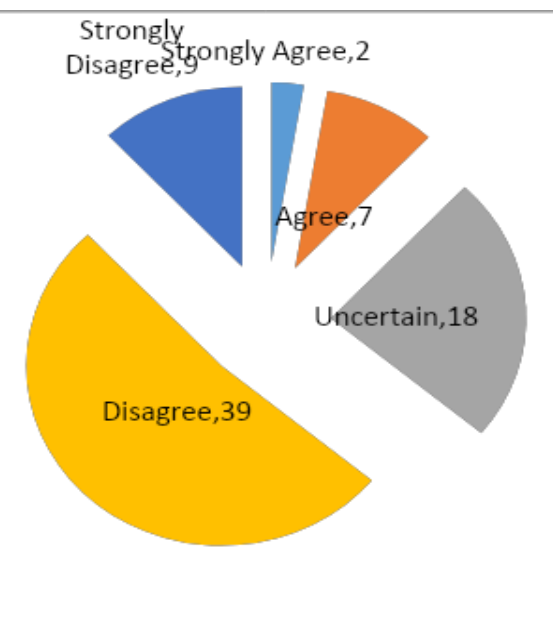

This graph shows $39 \%$ diagree that many zambians know the inportannce of the zambian Ombudsman office. While $18 \%$ are uncertain and only $2 \%$ agree that many zambians knows the importance of the office of zambia Ombudsman, 7\% agree and 9\% strongly agree with the statement. 


\subsection{DISCUSSION}

It is very clear that from the nature of the Cases Commission for Investigation \{ZambiaOmbudsman \} receive that not many people are acquainted with the Legal provisions relating to their work or operations and very few understand their specific mandates, which leads to Complaints being misdirected. This situation is attributed to their failure to publicize their work or operations.

The Institution $\{\mathbf{C I} / \mathbf{Z O}\}$ office strives to attain Hundred Percent $\{100 \%\}$ Cease resolution for each year. However, their Operations is hampered in many ways by problems relating to inadequate human resources, lack of essential equipment and embedded in the enabling Legislation. In addition, the Commission for Investigations \{Zambia-Ombudsman\} Suffers from the fact that it has only one central office. The net effect of these factors is to undermine the effective execution of the mandates of the Zambian-Ombudsman/Commission for Investigations operations. Cases are delayed, causing further injustices in the long run.

Zambian Ombudsman's Office \{Commission for Investigations\} is a Creature of the Zambia Constitution and it was created out of a felt need to curb Human-rights abuse and injustices at various levels. Although, the Commission is not a dependent on any Government Ministry for its Operations, but it's dependent on Government funding. It is an executive Commission which report directly to the republican President to halt an Investigation. The Officials of the Commission feel that it should be a Parliamentary Institutions and that it should be reporting to Parliament directly, which would guarantee the Commission true Autonomy.

\section{CONCLUSION AND RECOMMENDATIONS}

In conclusion although, Judging by the Legal framework in place the situation is not alarming, it is important that the findings of Commission for Investigations \{Zambia Ombudsman Office\} be taken very seriously and positive steps be taken to ensure that the functions effectively. The Commission for Investigations \{Zambian Ombudsman Office\}, is a government institution and, in the face of findings listed above, it is incumbent upon the government to come up with policies that will ensure such effective Functioning.

The following are, therefore, some recommendations that may help the problems at the Commission for Investigations \{Zambian Ombudsman's office\}.

1. In order to have the Commission for Investigations \{Zambian Ombudsman\}, implement its mandates fully, there is an urgent need for the government to increase their findings. Further, the funding must be released on time and in full, not, as at present, in the form of piecemeal or gradually grants. Monthly grants have proved to be ineffective and lead to delays in the implementations of programmed

2. There is a need to strengthen the operations of Commission for Investigations by acting promptly on the recommendations make. It is therefore felt that there should be a deliberate effort to treat the recommendations with the urgency they deserve, especially as the issues relate to abuse of office, maladministration, social injustices in public Institutions

\section{BIBLIOGRAPHY/REFERENCES}

[1] Adamolekun, Ladipo \{2002\}: Public Administration in Africa. Ibadan, Spectrum Books Limited.

[2] Adamolekun, Ladipo \{1985\}: 'Nigeria's Ombudsman System: A National Network of Public Complaints Commissions' in Adamolekun, L. \{ed.\} Nigeria Public Administration 1960-1980 Perspective and Prospective. Ibadan, Heinemann Educational Books.

[3] Ake, Claude \{1993\}: 'Deeper in to Original Sin: The Context of theEthical Crisis in Africa Services' in SadiqRasheed and Dele Oluwo \{ed.\} Ethics and Accountability in Africa Public Services. Addis Ababa, African Association for Public Administration and Management and UNECA.

[4] Ayeni, O. Victor. \{2002\}: 'Botswana' in Adamolekun, Ladipo \{ed.\} Public Administration in Africa. Ibadan, Spectrum Books Limited.

[5] Barlow, C.H.M. \{1993\}: 'Ethical Codes for Africa Administration: Nature, Content, Limitations and Required Improvements' in SadiqRasheed and Dale Oluwo \{ed.\} Ethics and Accountability in African Public Services. AAPAM.

[6] Eboufaye \{2006\}: Office of the Ombudsman Public Relations, the Gambia. 
[7] Gawanas, B. \{2002\}: 'Office of the Ombudsman 1990-2000'. In M. Hinz, S. Amoo\& D van Wyk \{ed.\} The Constitution at Work- 10 years of Namibian nationhood.

[8] Kasuto E. \{1996\}: 'The Institute of Ombudsman in Namibia' in E. Kasuto\& A. Wehmhorner \{ed.\}: The Ombudsman in Southern Africa: Report of a Sub regional Conference. Windhoek: Friedrich Ebert Stiftung.

[9] Kiragu, Kithinji. \{200\}: 'Tanzania' in AdamolekunLadipo \{ed.\} Public Administration in Africa. Ibadan, Spectrum Books Limited.

[10] Makaramba, V. Roberts \{2002\}:The Commissions for Human Rights and Good Governance in Tanzania in Regional Workshop on enhancing the Public Profile of the Ombudsman's Office in Africa. $30^{\text {th }}$ January,- $3^{\text {rd }}$ February, Abuja. Nigeria.

[11] Maoka, M. V. \{2006\}: 'Current Situation and the Challenges faced by the Office of the Public Protector \{Ombudsman\} of South Africa' in a Workshop Enhancing the Public Profile of the Ombudsman's office in Africa. $30^{\text {th }}$ January, to $3^{\text {rd }}$ February, Abuja. Nigeria.

[12] Mazizi, Baba Mbulelo \{2006\}: 'Management of the Public Relations Functions of the Office of the City Ombudsman for the city of Cape Town, South Africa' in Regional Workshop Enhancing the public Profile of the Ombudsman Office in Africa. $30^{\text {th }}$ January, to $3^{\text {rd }}$ February, Abuja.Nigeria.

[13] McMillan, John \{2006\}: 'The Role of the Ombudsman in Protecting Human Rights' in an address to a Conference on Legislatures and the Protection of Human Rights. University of Melbourne, Faculty of Law, $21^{\text {st }}$ July.

[14] Musamba, M. Annet \{2006\}: 'Commission for Investigations \{Zambia Ombudsman's Office\} Regional Workshop on Enhancing the Public Profile of the Ombudsman's Office in Africa. Abuja, 30th January, to $3^{\text {rd }}$ February.

[15] Office of the Ombudsman,\{2006\&2007\}: Annual Report. Windhoek: Office of the Ombudsman.

[16] Olowu, Dele \{2002\}: 'Accountability and transparency' in AdamolekunLadipo \{ed.\} Public Administration in Africa. Ibadan, Spectrum Books Limited.

[17] Oosting, M. \{1996\}: 'The Ombudsman: A Profession'. This is a Workshop Paper delivered at the International Ombudsman Institute, Netherlands. The Workshop was titled Strengthening the Ombudsman Office in Africa. 26 ${ }^{\text {th }}$ August.

\section{AUTHORS' BIOGRAPHY}

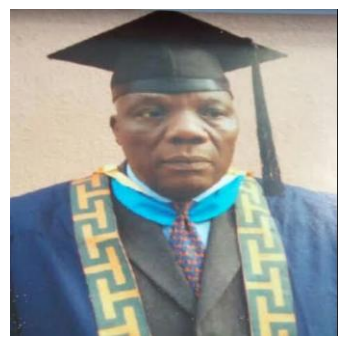

I Ramap Bedding is a Holder of Diploma in Law, Bachelor Degree in Law (LLB), and Masters

Degree in Criminal Justice System (LLM).

Ramap Bedding has other various Qualifications in different Disciples and professions. He became the Coordinator for Legal Aid Clinic in Conjunction with LAW ASSOCIATION of Zambia, prior to that He helped to Revamp the Legal Aid Clinic for Women and Children International Zambia Chapter that was closed for Five Years.

Mr. Bedding once worked as an Intern at Chifumu Banda and Associates for two years and also as part time jobs as Lecturer at Livingston International University, Cavendish University Zambia, Zambia Open University and University of Africa in Criminal Law, Jurisprudence, Criminal and Civil Procedure, Legal Process, Adminstrative Law and Intellectual property Law.

Currently, He is a Heads of Department School of LAW and Humanities at University of Africa ZAMBIA.

Citation: Ramap David Binven Bedding, Tawonga David Bedding. "Awareness and Importance of the Role of the Office of the Obudusman in Selected Institutions in Zambia" International Journal of Humanities Social Sciences and Education (IJHSSE), vol 7, no. 10, 2020, pp. 43-50. doi: https://doi.org/10.20431/23490381.0710005 .

Copyright: () 2020 Authors. This is an open-access article distributed under the terms of the Creative Commons Attribution License, which permits unrestricted use, distribution, and reproduction in any medium, provided the original author and source are credited. 